\title{
The Effect of "Quantum Learning" Model Using "Mind Mapping" Technique to Eight Grade Students' Creative Thinking Ability
}

\author{
Erik Eriyanto, Siti Inganah, Dwi Priyo Utomo
}

\author{
Department of Mathematics Education, Faculty of Teacher Training and Education, \\ University of Muhammadiyah Malang \\ erikriyant080@gmail.com
}

\begin{abstract}
This study aims to determine how the effect of the Quantum Learning model using Mind Mapping techniques to students' creative thinking abilities. The type of research used is experiment and quantitative approach with research design using posttest only group design. Data analysis of two groups used the t-test on SPSS 21, that is Independent Sample t-Test to test the difference in average posttest value of two samples.

The results of this study are (1) results of the t-test from post-test data obtain a significance 0,000 where it is lower than 0.05 so can be said that the average of the two groups are different, (2) from the post-test results, the answers given by students from the experimental group more fulfilled the indicators of creative thinking than students from the control group.

Keywords: Quantum Learning, Mind Mapping, Creative Thinking
\end{abstract}

\section{INTRODUCTION}

Learning in schools is one of the medium to improve the quality of education (Saifulloh, Muhibbin, \& Hermanto, 2012). If the learning process in school does not optimal, it can be preconcerted that the education quality is not good. The education quality in Indonesia that requires quality improvement is mathematics, considering those mathematics is a basic science that can train students to think critically and logically (Sudia \& Majja, 2016). Skills in counting and logical thinking must be improved. Students still face up many difficulties in accepting math learning because mathematics is abstract and has many symbols (Soedjadi, 2000).

Quantum learning was initiated by DePorter by providing a comfortable and enjoyable atmosphere in learning so that students can gain new experiences in learning. This statement is consistent with the sentence that Samad (2015) did, that the learning outcomes of tenth-grade students of SMAN 2 Makassar increased after applying a quantum learning model in the learning process.

The effort that can be applied to improve the quality of education is by matching the learning model with the growth of students' thinking patterns. By applying the correct learning model, teachers can engage students in learning. Teachers can use the Quantum Learning learning model as an alternative learning model when a teacher deliver the learning materials in the classroom.

The learning model that can provide a suggestion that learning must happen feedback between teachers and students is the Quantum Learning model (Mohiddin, 2016). Education and learning activities using quantum learning models need to involve 
students in comfortable situations and be content with learning done (Arifin, 2011). Quantum learning can adapt students to their learning environment, thus affecting the learning process and learning outcomes (Huda, 2013). In this way, learning using a quantum learning model can excite the interest of the student because teacher free up the student's learning style in learning activities and makes the student's learning more comfortable.

According to DePorter \& Hernacki (Arifin, Sudarti, \& Lesmono, 2016), Quantum Learning is a learning model that can improve understanding and memory and give understanding to students that learning is a pleasant process and useful. This description shows that the quantum learning model can be applied to various teaching materials in each subject as long as the learning process is performed in a pleasant and comfortable way. This is also supported by Miftahul Huda's decision (2013) that students can learn more easily in a comfortable and supportive environment.

Mind mapping can be thought more creatively because you can use colors and symbols in mind maps as well as stick to memory. Mind mapping technique was first initiated by Tony Buzan. According to Buzan (Huda, 2013), it is assumed that someone usually starts the main idea from the middle of the page, from there he can extend his idea in all directions and create a kind of diagram consisting of ideas and symbols.

Learning in the right way can improve students' creative thinking skills by learning math. Creative thinking is an activity about how to think to make something different in achieving its goals. Widiawan (Tirtawatti, Adnyana, and Widiyati, 2014) states that creative thinking is a process of doing something different than the preparation being considered. Mathematics learning will be more interesting if learning feels fun and active so the students can improve their creative thinking skills. Learning techniques that can stimulate students' creative thinking is using mind mapping learning techniques.

Mind mapping aims to give students the chance to take note subjects by mapping ideas using desired symbols and colors. Using this model, a teacher can teach students to create a mind map and students use their mind maps in identify facts clearly.

Arnyana (Putu \& Ida, 2016) states that creative thinking is the ability to develop or find original, aesthetic, and constructive ideas by using the basic thought process to process information rationally and intuitively to bring out the original perspective of the thinker. According to Isaksen et al. (Mahmudi, 2010) Creative thinking is a series of actions that make up an idea that highlights four aspects: fluency, flexibility, originality, and elaboration. Based on the above, the author's goal is to examine the effects of applying a quantum learning model using mind-mapping technique to eighth-grade students' creative thinking ability.

\section{RESEARCH METHODS}

The type of research used in this study is quasi-experimental research using a quantitative approach. The researcher used a post-test only group design to get research data. This research is intended to provide a description of how the effects of quantum learning models use mind mapping techniques to students' creative thinking abilities. The location used in this research was SMPN 5 Trenggalek. The researchers took samples of 64 students from two selected groups, each group represented by 32 students. Research data obtained from the results of post-study tests after learning consisted of the application of learning by quantum learning models using mind mapping techniques. 
After analyzing the post-test data for normality and homogeneity, hypotheses were tested using the SPSS program's that are using independent t-test.

\section{RESULTS AND DISCUSSION}

Normality tests are done to prove that the data being analyzed be normally distributed. Tests were done using SPSS 21 program with the normality tests Kolmogorov-Smirnov and Shapiro-Wilk. The hypotheses used in this normality test are:

$H_{0}=$ data is normally distributed

$H_{1}=$ data is not normally distributed

The results of the normality test using SPSS 21 can be seen in the following table:

\begin{tabular}{ccccl}
\multicolumn{6}{c}{ Table 1 Test the Normality of Posttest Value Data } \\
\hline No. & Group & Sig $_{\text {count }}$ & Sig $_{\text {min }}$ & \multicolumn{1}{c}{ Description } \\
\hline 1. & Experiental Group & 0,068 & 0,05 & $\begin{array}{l}\text { data is normally } \\
\text { distributed }\end{array}$ \\
\hline 2. & Control Group & 0,061 & 0,05 & $\begin{array}{l}\text { data is normally } \\
\text { distributed }\end{array}$ \\
\hline
\end{tabular}

Based on the obtained table, the significant value of the post-test of the creative thinking ability of the experimental group is 0.068 , and the significant value of the post-test of the creative thinking ability of the control group is 0.061 . Since both have values lower than 0.05 , then $H_{0}$ is accepted, so it can be concluded that the two groups of post-test data are normally distributed.

A homogeneity test was performed as a prerequisite analysis to determine if the experimental and control group data were homogeneous. Testing is done using SPSS 21 in Lavene Test's statistical formula. The hypotheses used in the homogeneity test are:

$H_{0}: \sigma_{1}^{2}=\sigma_{1}^{2}$, the variance of the two samples are homogeneous

$H_{1}: \sigma_{1}^{2} \neq \sigma_{2}^{2}$, the variance of the two samples are not homogeneous

The results of the homogeneity test with SPSS 21 can be seen in the following table:

Table 2 Test Homogeneity of Posttest Value Data

\begin{tabular}{ccccc}
\hline No. & \multicolumn{1}{c}{ Data } & Sig $_{\text {count }}$ & Sig $_{\text {min }}$ & \multicolumn{1}{c}{ Description } \\
\hline 1. & $\begin{array}{l}\text { Posttest value of } \\
\text { experimental and control } \\
\text { group }\end{array}$ & 0,123 & 0,05 & $\begin{array}{l}\text { Varians homogen/ } \\
\text { identik }\end{array}$ \\
\hline
\end{tabular}

Based on the table, the calculated significance value of the creative thinking ability posttest value is 0.123 . The significance value is greater than the least significant of 0.05 , so hypothesis $H_{0}$ is accepted or the variance of the experimental and control group is homogeneous/identical.

The test hypotheses using the independent sample t-test of the statistical formula make it possible to test the differences between the mean post-test values of the two groups, using the following hypothesis:

$H_{0}=$ the average value of the two groups is the same (there is no effect of the Quantum Learning model by using mind mapping techniques on students' creative thinking abilities)

$H_{1}=$ the average value of the two groups is different (there is the effect of Quantum Learning model by using Mind Mapping techniques on students' creative thinking abilities)

The results of the hypothesis test using SPSS 21 are shown in the following table:

Table 3 Hypothesis Testing

\begin{tabular}{lcc}
\hline \multicolumn{1}{c}{ Observed material } & Experimental Group & Control Group \\
\hline Mean & 63,20 & 48,13 \\
\hline Sum & 32 & 32 \\
\hline
\end{tabular}




\begin{tabular}{lc}
\hline Sig. $(2$-tailed $)$ & 0,000 \\
\hline Description & the average value of the two groups is different \\
\hline
\end{tabular}

From Table 3, it is known that the average difference between the experimental class and the control class is 15.07. Thus, the analysis of the data shows that the significance of the t-test from post-test data has a value of 0.000 . The calculated level of significance is less than 0.05 . It can be concluded that the average of creative thinking ability from the experimental group and the control group is different or not identical. Then, we can say that H_0 is rejected, which means that the average post-test value of the two classes is different (there is the effect of the Quantum Learning model using mind mapping techniques on students' creative thinking abilities).

In this research, researchers measured students' creative thinking using post-test questions. Below you will find a more detailed explanation of how creative thinking skills of students in the experimental group are explained.

\section{Fluency}

The first question to ask after the test is to measure students' fluency indicators when solving problems. The achievement of this indicator is shown in the variety of responses provided by the students. In question number one, students are instructed to create examples of relationships in everyday life in different forms.

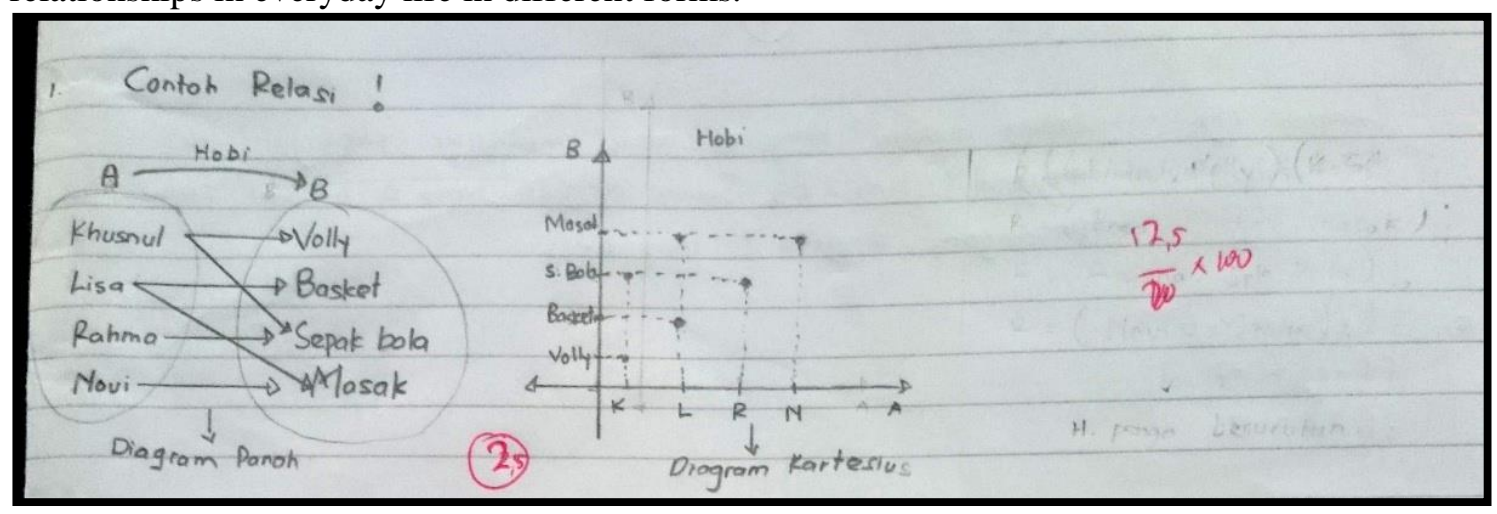

Picture 1 Answer of Question Number One

Picture1 illustrates the students' creative thinking skills on fluency indicators, with a score of 2.5 out of a maximum of 4 . Students are able to write two correct answers in different forms, but still in the same example relationship.

\section{Flexibility}

The second post-test question is to measure students' Flexibility indicators when solving problems. Achieving this indicator is reflected in the variety of ideas with different perspectives for problem solving. In question number two students are instructed to make a relation of the two sets given using various forms of presentation.

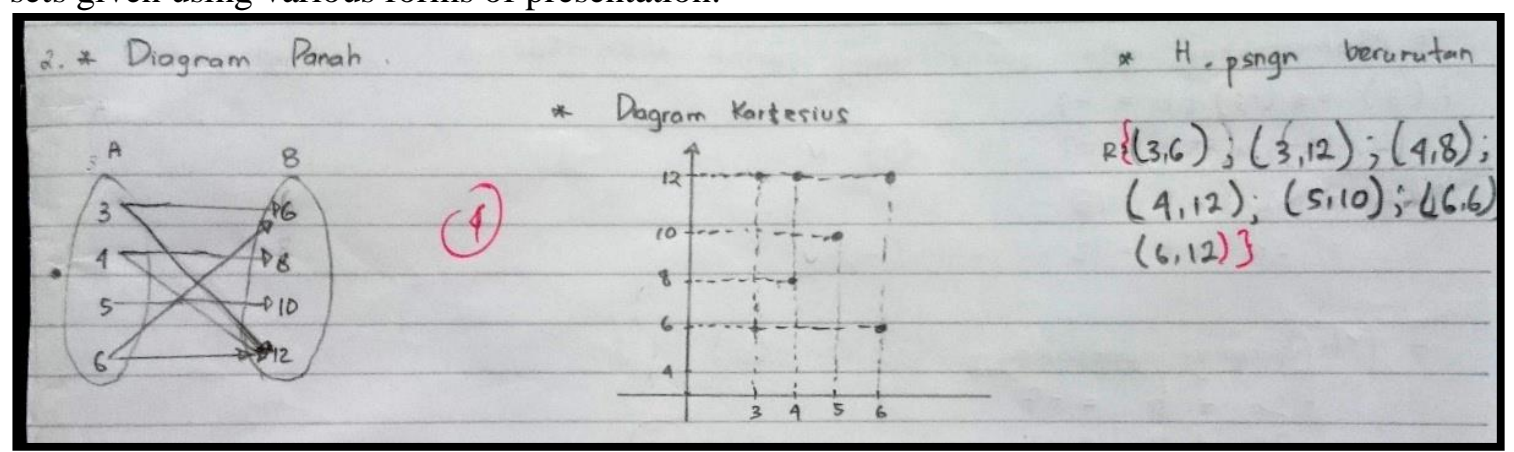

Picture 2 Answer of Question Number Two 
Picture 2 is an example of students' creative thinking skills on flexibility indicators, with a score of 4 out of a maximum of 4 . Students can write three forms of presentation correctly determine the relationship between two sets.

\section{Originality}

The question of posttest number 3 is to measure the originality of student responses to problem solving. The achievement of this indicator is illustrated by the way student to discover something from the problem posed. In the third question, students are instructed to make some statements that can be revealed from given relations using their own language.

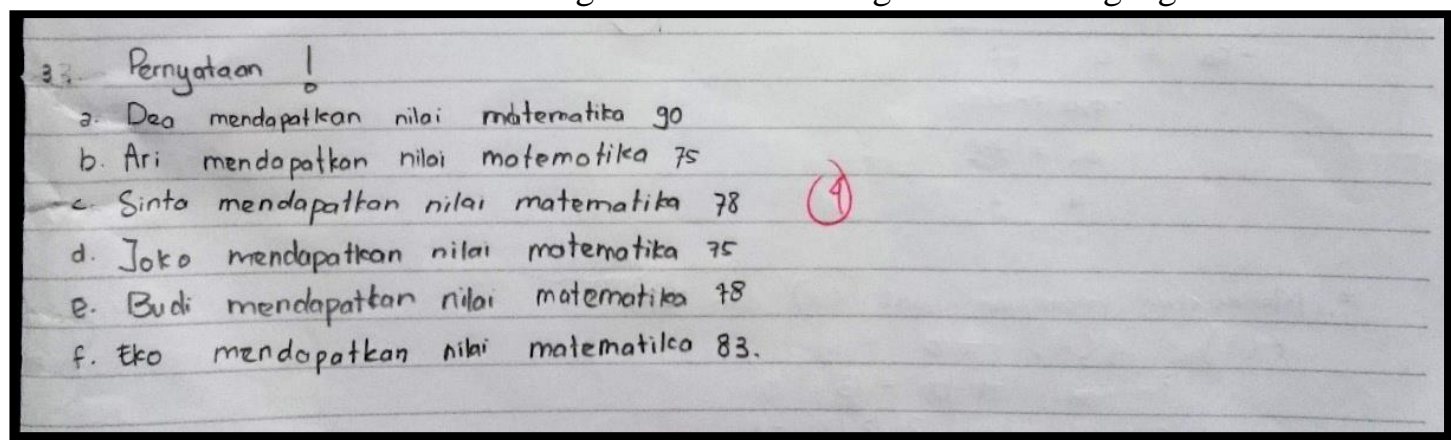

Picture 3 Answer of Question Number Three

Picture 3 is an example of students' creative thinking skills on the indicator of originality, with a score of 4 out of a maximum of 4 . Students can give an answer in their own way to discover the statement in accordance with the relations between two sets.

\section{Elaboration}

Questions number four and five in Posttest are used to measure student development indicators for problem solving. The achievement of this indicator is illustrated by the fact that students are able to develop, add or detail an idea. In question number four, students are instructed to determine the rules that might occur for the function of the two sets given with explaining the steps.

4

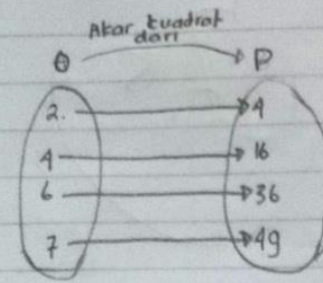

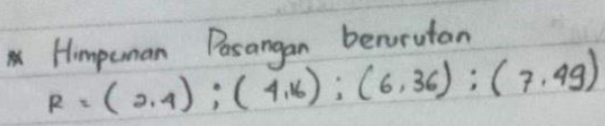

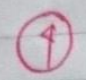

$$
\begin{aligned}
\text { Langkah Inya. Setrap anggota }{ }^{3} \text { Himp } 0 \text { harus memililei pasangan di } \\
\text { anggota } ? \mathrm{him} \text {. P, Setiop anggota himp o mamiliki satu } \\
\text { pasangan anggota ? himp } P \text {. }
\end{aligned}
$$

Picture 4 Answer of Question Number Four

Picture 4 is an example of student creative thinking performance on the elaboration indicator, with a score of 4 on the maximum score of 4 . Students are able to detail an idea he has by writing the steps.

In question number five, students are asked to determine the function formula of the information given in the problem by explaining the steps and graphing their functions. 


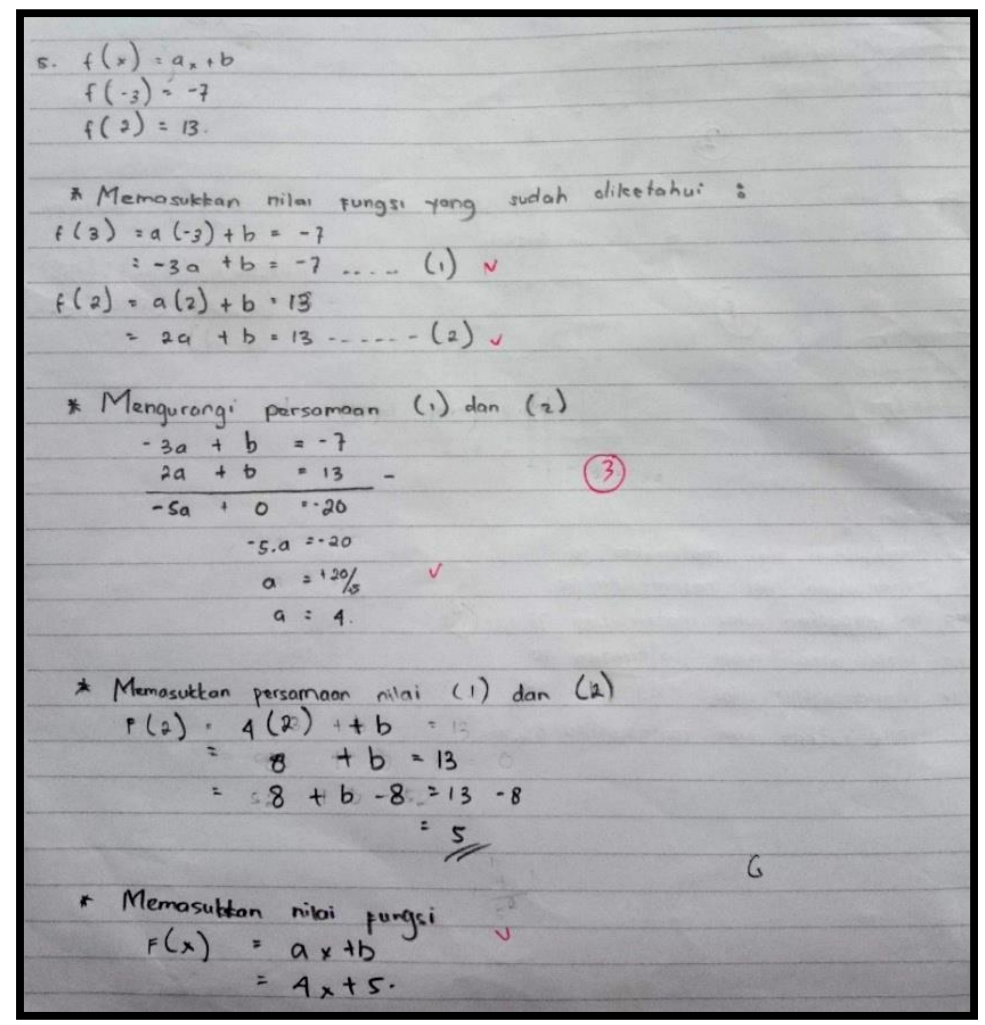

Picture 5 Answer of Question Number Five

Picture 5 is also an example of students' creative thinking skills on the elaboration indicator, with a score of 3 on the maximum score 4 . Students can detail the ideas they have in writing the steps, but there are still errors in the answer, students can not draw functions.

Based on post-test results after treatment of both groups, many indicators of creative thinking ability appeared in the experimental group that treated with Quantum Learning models using the mind mapping techniques than the control group with conventional models. It is also apparent from the comparison of the average test score of the experimental group of 63.20 , which is higher than the average value of the post-test of the control group, which is only 48.13 . Therefore, it can be concluded that the achievement of creative thinking indicators is more achieved by the experimental group than by the control class.

The results of this study are reinforced by previous research in a study entitled "The Effect of Quantum Learning Application using Mind Mapping on seven grade Mathematics Student Learning Outcomes of SMP Negeri 1 Batam 2014/2015 Academic Year" obtained the results of research that the Quantum Learning learning model with Mind Mapping has a good effect to the learning outcomes of seven grade students of SMP Negeri 1 Batam in 2014/2015 Academic Year (Putra \& Martini, 2015).

\section{CONCLUSION}

The conclusions drawn from the results of research carried out from the application of the quantum learning model using mind mapping techniques in mathematics subjects to junior high school eighth grade student, that is:

1. The quantum learning model using mind maps has a positive significant effect on students' creative thinking abilities.

2. The creative thinking ability of students from both groups seen from the test results explained that answers from students in the experimental group more fulfilling creative thinking indicators than students in the control group. 


\section{REFERENCES}

Arifin, Z.. (2011). Quantum Learning and Teaching: Menuju Arah Pembelajaran Bermakna. Alfikra: Jurnal Ilmiah Keislaman, 10(1).

Arifin, Z. Sudarti, \& Lesmono A. D. (2016). Pengaruh Model Quantum Learning Disertai Metode Eksperimen Terhadap Hasil Belajar Fisika Siswa di SMS Negeri Kalisat. Jurnal Pembelajaran Fisika, 4(4), 365-370.

Huda, Miftahul. (2013). Model-model Pengajaran dan Pembelajaran: Isu-isu Metodis dan Pradigmatis. Yogyakarta: PUSTAKA PELAJAR.

Mahmudi, A. (2010). Mengukur Kemampuan Berpikir Kreatif Matematis. Makalah disajikan pada Konferensi Nasional Matematika XV UNIMA. Manado: Jurusan Matematika UNY.

Mohiddin, D. P.. (2016). Pengaruh Model Pembelajaran Quantum Teaching dan Kemampuan Berpikir Matematis Terhadap Hasil Belajar Siswa. Jtech, 4(2), 90 - 93.

Putra, J.D., \& Martini, J. (2015). Pengaruh Penerapan Quantum Learning dengan Mind Mapping terhadap Hasil Belajar Matematika Siswa Kelas VII SMP Negeri 1 Batam Tahun Pelajaran 2014/2015. PYTHAGORAS, 4(2), 43-55.

Putu, A. \& Ida, B. (2016). Pengaruh Penerapan Strategi Pembelajaran Inovatif pada Pelajaran Biologi Terhadap Kemampuan Berpikir Kreatif Siswa SMA. ISSN 0215-8250: Jurnal Pendidikan dan Pengajaran IKIP Negeri Singaraja, (4)

Samad, I.. (2015). Peningkatan Hasil Belajar Matematika Melalui Pembelajaran Quantum Learning. Pedagogy,2(1).

Saifulloh, M., Muhibbin, Z., \& Hermanto. 2012. Strategi Peningkatan Mutu di Sekolah. Jurnal Sosial Humaniora, 5(2).

Soedjadi, R.. (2000). Kiat Pendidikan Matematika di Indonesia. Jakarta: Direktorat Jendral Pendidikan Tinggi Departemen Pendidikan Nasional.

Sudia, M., \& Majja, M. (2016). Pengaruh Motivasi Berprestasi Melalui Kombinasi Model Pembelajaran Kooperatif Terhadap Hasil Belajar Matematika. Jurnal Pendidikan Matematika, 7(1), 1-13.

Tirtawati, Ni L. R., Adnyana, P. B., \& Widiyanti, Ni L. P. M.. (2014). Pengaruh Pembelajaran Kuantum (Quantum Learning) dan Peta Pikiran (Mind Mapping) Terhadap Keterampilan Berpikir Kreatif dan Hasil Belajar Biologi Siswa SMA. E-Journal Program Pascasarjana Universitas Pendidikan Ganesha, Program Studi IPA, 4. 